Vol. 7, No. 1, 2017

\title{
USE OF CLUSTER ANALYSIS METHOD TO INCREASE THE EFFICIENCY AND ACCURACY OF RADAR DATA PROCESSING
}

\author{
Ivan Karlashevych, Volodymyr Pravda \\ National Technical University of Ukraine "Igor Sikorsky Kyiv Polytechnic Institute", Kyiv, Ukraine \\ karlashevich@ukr.net
}

(C) Karlashevych I., Pravda V., 2017

\begin{abstract}
The article presents a range of solutions to improve the efficiency and accuracy of multiradar data processing. For this purpose the method of cluster analysis is proposed, basing on which, authors have made an improvement to the classical algorithm of the rejection of abnormal measurements and considered a possibility for implementing a multithread processing of radar data.

For paralleling the radar data processing, the method of the separation of radar stations with the use of the cluster analysis method is proposed. This leads to the reduction of load on the computing power of radar system and reduces the time required for data processing.

On the basis of the developed program, the accuracy of radar data processing has been improved by about $10 \%$. As a result, the new algorithm is able to work under the regular occurrence of abnormal emissions and does not require a whole set of measured data for correct work.

Being compared to existing solutions, methods and algorithms suggested by the authors support the current trend towards multithreaded data processing and are based on the new methods of intellectual analysis.

These solutions are assigned for the use in future systems of collecting and processing the radar data.
\end{abstract}

Key words: multiradar data processing, radiolocation, cluster analysis method, accuracy, cluster.

\section{Introduction}

The emergence of new types of aircraft, increasing speeds and maneuverability makes improving the efficiency of processing radar information and using modern analysis techniques the actual theme of $\mathrm{R} \& \mathrm{D}$.

One of the modern methods of analysis is a cluster method. It can be used to improve the efficiency and accuracy of radar information processing.

Significant efficiency of radar data processing is achieved by cluster method creating groups for parallel processing of radar data streams in multiposition radar systems.

Implementation of radar data processing from the radar systems needs to create a centre for collecting and processing radar information (CCPRI). At the same time, there are high demands on the computing power of CCPRI.

2. Parallelization of multiradar processing of radar data

The parallelization of multiradar processing of radar data facilitates problem solving and creates several advantages: independent data processing in each stream, reducing the amounts of data.

The method of division of data among threads implies creating an array of input data $\stackrel{I}{I}=\left(i_{1}, \ldots, i_{k}\right)$ from a plurality of sources of radar data $\stackrel{\prime}{S}=\left(s_{1}, \ldots, s_{k}\right)$. This data stream is divided into groups by each source of radar data and the array of sources is divided into independent subarrays $\stackrel{\prime}{F}=\left(f_{1}, \ldots, f_{k}\right)$.

Separating data is possible by a spatial sign. The airspace is divided into zones in which radar data is processed by cluster analysis based on the criterion of minimum distance between objects.

The procedure for dividing into clusters looks as follows.

There are coordinates $(x, y)$ and the maximum detection range $D_{\max }$ for each source from plurality $S$.

Then the distance $L$ between a pair of sources $S_{i}$ and $S_{j}$ equals

$$
L_{i j}=\left(x_{i}-x_{j}\right)^{2}+\left(y_{i}-y_{j}\right)^{2} .
$$

Formation into groups $\mathrm{F}$ is performed by rule

$$
L_{i j}<D_{\max i}+D_{\max j}-R, S_{i} \in F_{z}, S_{j} \in F_{z},
$$

where $F_{z}$ is Z-group of radar data sources; $R$ is a pre-set strobe that characterizes the value of intersection of areas with identified sources.

\section{Improving the rejection algorithm}

Using the method of cluster analysis for handling the radar data in real time increases the accuracy of multiradar data processing by rejection of abnormal measurements with regard to maximum permissible speed. 
This algorithm performs rejection of gross measurement errors on the assumption that the speed of the aircraft cannot exceed its maximum speed $V_{\text {max }}$, which means that measure cannot be very different from the previous one.

Let us compare the classical algorithm of the rejection of abnormal measurements and the algorithm with the use of the cluster analysis method.

Let us consider the work of classical rejection algorithm on the data sample coming from a threedimensional (3-D) radar. $N$ is an input vector of data measured with the parameters of a target: $T, D, A, E$, where $T$ is time of measurements, $D$ is a distance to the aircraft, $A$ and $E$ are azimuth and elevation angle of the aircraft. Set $H$ of measured data characterizes rectangular coordinates $Q(X, Y, Z)$ of the aircraft location.

Thus, for the rejection of abnormal parameters measured we need:

- to calculate the speed of the aircraft between the last point in the data sample obtained in rectangular coordinates and current measuring:

$V_{N+1}=\frac{\sqrt{\left(X_{N+1}-X_{N}\right)^{2}+\left(Y_{N+1}-Y_{N}\right)^{2}+\left(Z_{N+1}-Z_{N}\right)^{2}}}{T_{N+1}-T_{N}}$

- check the value of calculated speed on admissibility:

$$
V_{N+1} \leq V_{\max },
$$

if the condition is not fulfilled, the parameters of the point are considered to be abnormal and the whole vector is excluded from processing.

Under these conditions, the abnormal measurement rejection algorithm with regard to maximum allowable speed has following disadvantages:

1. The algorithm is not able to work under regular occurrence of abnormal emissions.

2. To determine the speed of the aircraft, the algorithm requires to use the set of measured data $(T, D$, $A, E)$ for determining the rectangular coordinate $Q(X, Y, Z)$ of the aircraft location.

3. Transforming polar coordinates to rectangular causes information losses about the distortion of the parameter.

4. Two valid parameters could be lost due to the occurrence of one abnormal.

The method of cluster analysis does not have these drawbacks.
With the help of the developed software, the results of the work of the classical rejection algorithm (Fig. 1) and the rejection algorithm using the cluster analysis (Fig. 2) have been obtained.

The number of jumps is determined depending on value of elevation angle during chosen time of analysis.

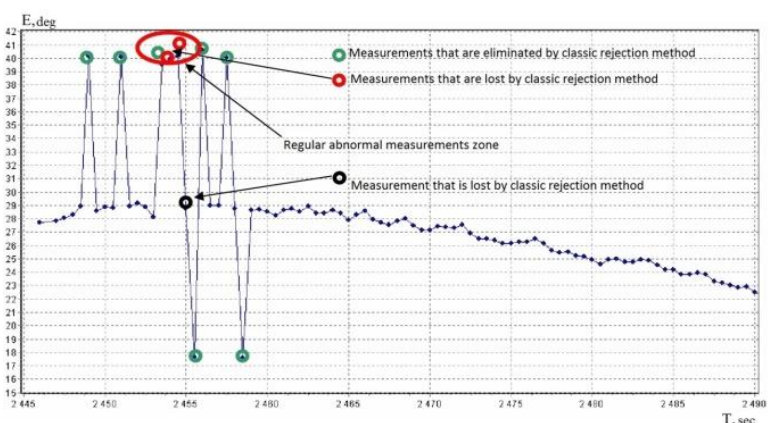

Fig. 1. Results of work of classical rejection algorithm.

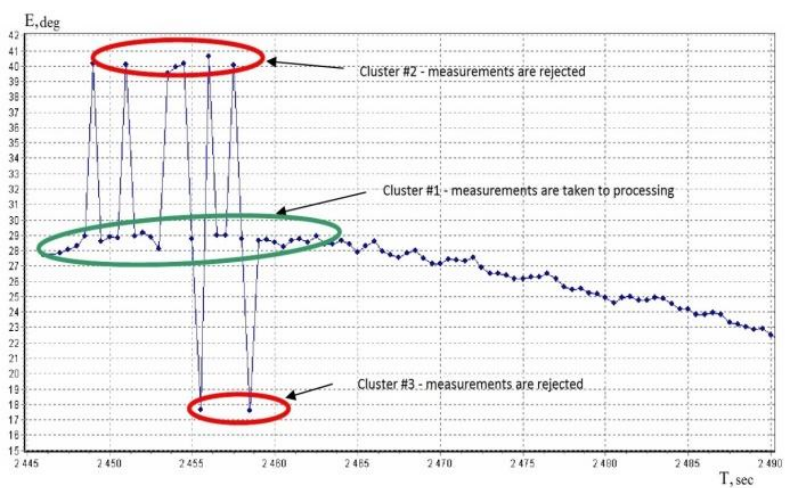

Fig. 2. Results of work of rejection algorithm using the cluster analysis.

Basing on the fact that each parameter is determined by an individual radar measuring channel, let us apply the cluster analysis to each parameter separately.

Metrics selection is based on the principle of using a priori data on physical characteristics of the aircraft, namely, the speed change of the aircraft over the given period of time is limited. Therefore, the changes of the measured parameters are also limited and they should vary smoothly and without abrupt emissions.

For each current parameter value, its inclusion in one of the current clusters is considered using the proposed mechanism for cluster replenishment and data removal. If the jumps of measured parameters take place and they cannot be included into any existing cluster due to their not falling under the relevant conditions, the decision is made to create a new cluster, in which the current parameter is included.

Since only the fullest cluster is intended for processing, occasional jumps of parameters are not taken into consideration. 
Maximum speed of measuring the azimuth and elevation angle depends on maximum possible radial velocity of the aircraft at a measured distance.

$$
V_{A \max }=V_{E \max }=\arcsin \left(\frac{V_{A \max }}{D}\right) .
$$

Clusters are reviewed by turns in descending order of time of recording data into the cluster according to the requirement:

$$
T_{\text {cur }}-T \frac{K}{N} \leq T_{\text {dif }},
$$

where $T_{d i f}$ is maximum time difference between the last parameter and the current parameter. The value of time is determined by the tactical and technical characteristics of the aircraft, and the rate of measurement is given at the planning stage; $T_{\text {cur }}$ is time of the current parameter of the aircraft; $T \frac{K}{N}$ is time of the last parameter recorded in the $K$-th cluster; $K$ is the number of the cluster; $N$ is the number of parameters recorded in cluster $K$.

Depending on the number of parameters recorded in the cluster, the approximation of the parameter by polynomial $P(t)$ at current time $-t_{\text {cur }}$ is performed

$$
P\left(t_{\text {cur }}\right)=\left\{\begin{array}{c}
a t^{2}+b t+c, \text { when } N \geq 4 \\
a t+b, \text { when } 2 \leq N<4 \\
P\left(t_{1}\right), \text { when } N=1
\end{array}\right\} .
$$

The discrepancy in the rate of change of the parameter is determined by formula:

$$
\Delta V_{A}=\frac{W \cdot\left|P_{A}-P\left(t_{c u r}\right)\right|}{\left(T_{c u r}-T \frac{K}{N}\right)},
$$

where $\mathrm{W}$ is a weight coefficient which is determined according to the number of parameters recorded in the cluster.

$$
W=\left\{\begin{array}{c}
10, \text { when } N \geq 10 \\
N, \text { when } 1 \leq N \leq 10
\end{array}\right\} .
$$

The found discrepancy in speed is compared with the maximum speed for a given parameter

$$
\Delta V_{A} \leq V_{P \max } .
$$

Under this condition, the measured parameter is included in the current cluster, otherwise next cluster is checked. If no suitable cluster exists, new cluster for this parameter is created.

The measurements from the cluster with the largest number of parameters are taken for processing.

This method will be more resistant to the accidental appearance of regular jumps.
For the considered case, the algorithm using cluster analysis was more effective than that without it by about $10 \%$.

Further increasing of efficiency is possible by the improvement of the algorithm of radar data processing.

The developed program enables radar data processing with the pace of survey of about 10 seconds per 200 targets from 64 radars.

\section{Conclusions}

Cluster analysis method allows the significant improvement of the efficiency and accuracy of processing radar information by the implementation of threading of data processing and the improved algorithm of rejection.

\section{References}

[1] S. Kuzmin, Digital radiolocation. Kyiv, Ukraine: KVIC, 2000. (Russian).

[2] I. Mandel, Cluster analysis. Moscow, Russia: Finance and statistics, 1988. (Russian).

[3] B. Duran and P. Odell, Cluster analysis. Moscow, Russia: Statistics, 1977. (Russian)

[4] Electronic textbook of statistics, Moscow, Russia: StatSoft Inc, 2001. (Russian).

http://www.statsoft.ru/home/textbook/default.htm.

\section{ВИКОРИСТАННЯ КЛАСТЕРНОГО МЕТОДУ АНАЛІЗУ \\ ДЛЯ ПІДВИЩЕННЯ ЕФЕКТИВНОСТІ \\ ТА ТОЧНОСТІ ОПРАЦЮВАННЯ РАДІОЛОКАЦІЙНОЇ ІНФОРМАЦІЇ}

\author{
Іван Карлашевич, Володимир Правда
}

Запропоновано низку вирішень проблеми недостатньої ефективності та точності мультирадарного опрацювання радіолокаційної інформації. Для цього запропоновано використовувати кластерний метод аналізу, на основі якого автори покращили класичний алгоритм відбракування аномальних вимірювань та розглянули можливість мультипоточного опрацювання радіолокаційної інформації.

Для розпаралелювання опрацювання запропоновано метод розділення радіолокаційних станцій на групи за допомогою методу кластерного аналізу. Це, своєю чергою, призводить до меншого навантаження на обчислювальні потужності радіолокаційної системи та зменшує час, необхідний на опрацювання даних.

За допомогою розробленої програми отримано підвищення точності близько $10 \%$. У результаті новий алгоритм здатен працювати в умовах появи регулярних аномальних викидів, для коректної роботи не потребує повного вектору вимірюваної інформації.

Порівняно $з$ уже наявними рішеннями, методи та алгоритми, що їх запропонували автори, підтримують сучасні тенденції до мультипоточного опрацювання даних та спираються на нові методи інтелектуального аналізу.

Подані рішення призначені для використання в перспективних системах збору й опрацювання радіолокаційної інформації. 


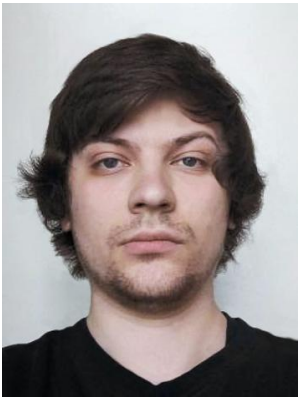

Ivan Karlashevych is a student of master's course at National Technical University of Ukraine "Igor Sikorsky Kyiv Polytechnic Institute". His scientific interests are radiolocation and tertiary processing of radar data.

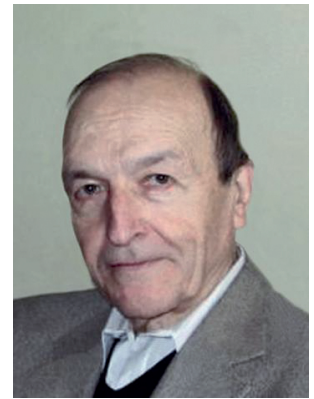

Volodymyr Pravda is the professor of National Technical University of Ukraine "Igor Sikorsky Kyiv Polytechnic Institute". His scientific interest is the development of systems and devices in the VHF range. 